Georgia State University

ScholarWorks @ Georgia State University

Early Childhood and Elementary Education

Faculty Publications

Early Childhood and Elementary Education

Department

2010

\title{
(Re)Storying Obama: An Examination of Recently Published Informational Texts
}

\author{
Laura A. May \\ Georgia State University, lauramay@gsu.edu \\ Teri Holbrook \\ Georgia State University, tholbrook@gsu.edu \\ Laura E. Meyers \\ Georgia State University, lemeyers@gsu.edu
}

Follow this and additional works at: https://scholarworks.gsu.edu/ece_facpub

Part of the Pre-Elementary, Early Childhood, Kindergarten Teacher Education Commons

\section{Recommended Citation}

May, L. A., Holbrook, T., \& Meyers, L. (2010). (Re)storying Obama: An examination of recently published informational texts. Children's Literature in Education, 41(4), 273-290. doi: 10.1007/s10583-010-9107-y

This Article is brought to you for free and open access by the Early Childhood and Elementary Education Department at ScholarWorks @ Georgia State University. It has been accepted for inclusion in Early Childhood and Elementary Education Faculty Publications by an authorized administrator of ScholarWorks @ Georgia State University. For more information, please contact scholarworks@gsu.edu. 


\title{
(Re)Storying Obama: An Examination of Recently \\ Published Informational Texts
}

\author{
Laura A. May, Teri Holbrook, \& Laura E. Meyers \\ Georgia State University
}

\begin{abstract}
American publishers have published numerous children's books about Barack Obama over the past several years; most take the form of informational biographies. This article reports on a research project aimed at how these books incorporate sociohistorical narratives, particularly those related to the civil rights movement. Though the features of the books might cause the reader to presume political neutrality, the books link readers to distinct Discourses (Gee, 1996), suggesting particular ideologies. In this article, we identified the following differences: (1) specific happenings from Obama's life were included in some texts while omitted in others; (2) when the events were included, how they were framed differed; and (3) the narrative constructions of the events varied. We use the differences amongst these texts to argue for the importance of critical literacy in elementary classrooms.
\end{abstract}

Laura A. May, Assistant Professor at Georgia State University, researches the texts teachers use in classroom literacy instruction, the classroom interactions that surround them, and how these two areas relate to teacher preparation. e-mail: lauramay@gsu.edu Teri Holbrook, Assistant Professor at Georgia State University, studies multiple literacies, technology, writing pedagogy, and the socio-cultural construction of learning disabilities. Laura E. Meyers, Assistant Professor at Georgia State University, studies social studies education, teacher development practices, cross-cultural immersion experiences, and children’s literature as it relates to literacy and social studies instruction. 
During the 2008 presidential campaign, a pre-service teacher in one of our university courses reported a complaint by the school media specialist at his field placement. While publishers were making available a growing number of books for children about Barack Obama, the librarian was having difficulty finding a comparable number of books about John McCain. Her interest in appearing nonpartisan was limiting the number of presidential campaign books she ordered. As we began examining the children's books about Obama, we thought about how difficult the media specialist's job must be. The books appeared similar; as nonfiction, they presented a seemingly neutral and factual account of the soon-to-be president's life. We wondered: How would teachers, media specialists, parents, and caregivers make their purchasing selections? As we thought more deeply about the situation, other questions arose: Amid the plethora of “facts" publicly available about historical figures, what conditions might lead authors to make decisions about which ones to include? Given the critical literacy stance that literacy is never neutral, how is neutrality portrayed in biographies for children, and how might presumed neutralities be disrupted? Are there underlying discourses informing authors' positions and decision-making, and how might adult readers understand and respond to those discourses to better guide children as they engage in these texts?

American publishers produced more than 20 children's books about Barack Obama between 2006 and the first months of 2009. As the calendar months pass, this number increases; at the time this article was written, the number had risen to more than 50. In our current times of fast capitalism (Agger, 1989; Gee, 2000), publishers must be nimble and quick to respond to market trends (Taxel, 2002). The speed with which these books have been published makes us pause. As U.S. citizens build our collective memory (Wertsch, 2002) of this historic figure, it is important to think critically about which stories we tell, which Discourses (Gee, 1996) we work 
from, and who benefits from the versions presented. In other words, there's no such thing as a neutral text. All texts draw on stories that have taken place within specific sociohistorical contexts working from particular ideological understandings. As consumers and citizens, we must think critically about the books we offer to our children. This work is especially important given general recognition of Obama as the first U.S. African American president (though even this general recognition is not shared by all Americans) and the potential ways in which his story will be taken up and used by different Discourse communities.

Barack Obama's ability to make his own story public—and thus help shape the biographical record about him—has been exceptional. He has written two memoirs (2004, 2006) and spoken often about his personal history. Additionally, Obama has been a part of the daily news, the topic of several biographies written for adults, and the object of significant pundit analysis from both traditional sources of commentary and the emerging blogosphere, all collectively influenced to various degrees by his autobiographical works. But, as we learned from Bruner (1987/2004), there are multiple ways to "story" a person, and multiple ways for a person to story his autobiography. When someone tells a story from his own life, he is not recounting an exact record of events. Rather, he is socially constructing or (re)interpreting what happened. He selects which parts to tell, how to portray those parts, which parts to leave out, etc. Therefore, an autobiographical account (oral or written) cannot be presented as a direct representation (Bruner, 1987/2004).

All cultures develop narratives that become part of their collective memory, and these narratives undergo challenges and revisions as multiple viewpoints and perspectives push back against conventional tellings. As the first African American president, Obama’s story undeniably will become part of the collective memory of the United States, affecting, among other 
understandings, how Americans conceptualize the development of civil rights in their country. But the history of the African American civil rights movement as a narrative project is a contested discourse. Williamson (2006) argued that cultural understandings of the civil rights movement rely on the "different frameworks [available] to tell the story of the black freedom struggle” (p. 39). She described conventional narratives [or meta-narratives (Banks, 2001)] as those that emphasized a "top-down" view of the political struggle in which national organizations led by prominent figures worked within receptive legal and political infrastructures to bring about change. Challenging these narratives are revisionists who have brought attention to local and grassroots organizations that engaged in lengthy and dangerous resistance against white racism and a reluctant and tepid federal apparatus. The differences in these two narratives are important, Williamson maintained, because conventional narratives support the notion "that moral suasion, normative and institutionalized routes to social reform'” are the only options, ignoring the unruly, ongoing, and often violent activism necessary to advance equity in the face of an entrenched and self-serving status quo. Furthermore, she posited that, in spite of important differences within and among scholarly work on this historical event, one ideological position— or to use Bruner’s term, “story”- - predominates in texts provided by schools: conventional narratives. In many ways, this preponderance is problematic because “"[b]y telling part of the story and leaving other parts of the story out, meta-narratives suggest not only that some parts of the story don’t count, but that some parts don't even exist’' (Banks, 1996).

Obama’s autobiographies necessarily reflect sociohistorical narratives that circulate within American culture. Given his position as the first African American president of the United States, his story in turn becomes part of the narratives by which children will make sense of 
American history—and themselves. For this reason, it is crucial for educators to review carefully and critically the biographies that frame Obama's life for children.

When biographers draw on an individual's self-account of his life, they do not simply restate the subject's story. Instead, they contribute their own re-storying, undergoing an additional selective process in which some events in the subject's life are included while others are omitted, some facts highlighted and expanded upon while others are diminished (Clandinin and Connelly, 1999). We argue that although certain non-fiction features such as glossaries, maps, photographs, reference lists, and timelines are used to portray the Obama biographies written for children as politically neutral, they link readers into distinct Discourses and, as a result, suggest particular ideologies. In this article, we report on a study in which we analyzed several non-fiction texts about Barack Obama written for elementary school aged-readers. The following questions guided this study: (a) How do the texts differ? and (b) What cultural narratives are suggested by the texts?

\section{Critically Examining Texts}

For the past several decades, educational researchers have critically examined texts written for children, including textbooks (Apple and Christian-Smith, 1991; Luke

et al., 1989; Williamson, 2006) and historical accounts (Kohl, 1995b; Taxel, 1981, 1997; Williamson, 2006), as well as changes in publishing industry decision-making as it relates to children's literature (Taxel, 2002). Researchers have looked at the ideological positions of texts (Baker, 2006; Jenkins, 2002; Lea, 2006; Travis, 2007) and demonstrated the complexity of authentic representation in multicultural texts (Fox and Short, 2003; Henderson, 2005; McNair, 2008; Tolson, 2005; Yokota and Bates, 2005). Across this work, findings indicated that, in spite 
of the neutrality assumed by expository text, the sociohistorical stories of one group of people predominates (i.e., European American, male, heterosexual, able-bodied).

As educators, we became interested in how biographies published for children navigate the multiple narratives related to Obama’s life. Because Obama’s election to the presidency has been storied as a key achievement in the move towards a more equitable society (Wise, 2009), we were interested in how the books incorporated (or did not incorporate) sociohistorical narratives, particularly those related to the civil rights movement.

\section{The Books}

Fourteen texts available for purchase at the time of our study comprised our data. Using Duke and Tower’s (2004) categories, each can be identified as a biography (i.e., a representation of information about a person, frequently someone who has overcome barriers and benefited others). Duke and Tower posited the following features as most likely to be found in biographies written for children: chronological organization; narratives of events in the person’s life told in third person, past tense; and a position regarding the individual's contribution to society (p. 135). While all of the books could be placed in the biography category in that they

“convey information about an individual’s life and experiences” (p. 135), and many were labeled by the publisher as biography, the books varied dramatically. While some told Obama’s story in narrative chapter-book format (Brill, 2006; Carlton and Gentiles, 2008; Edwards, 2007; Gormley, 2008; Mendell, 2008; Thomas, 2008), others were organized more like textbooks (DeMedeiros, 2008; Feinstein, 2008; Gibson, 2009; Wheeler, 2009). In other words, they had the text features typically found in textbooks (e.g., color photographs, bolded words that could be found in a glossary at the end of the book, text boxes with additional information). Some appeared to be hybrids of the two forms; they read as a narrative but also had limited non-fiction 
book features (DeVaney and DeVaney, 2006; Robinson, 2009; Schuman, 2008; Wagner, 2008). Of the books published at the time we began our analysis, we examined those that were available to us (i.e., not backordered or sold out). ${ }^{\mathrm{i}}$ Table 1 indicates the page length, age ranges of books' target audience, and text features included in the books. These factors could easily impact how an author storied Obama. For example, if an author had a photograph to support a point, she might present it differently in the print section. In this analysis, we did not take these factors into account; future research will address these issues.

\section{Table 1}

Total Number of Audience

Text Features

\section{Pages}

\begin{tabular}{|c|c|c|c|}
\hline \multirow[t]{7}{*}{ Brill (2006) } & 48 pages & Ages 9-12 & Color Photographs \\
\hline & & & Further Reading \\
\hline & & & Glossary \\
\hline & & & Index \\
\hline & & & Table of Contents \\
\hline & & & Text boxes \\
\hline & & & Timeline \\
\hline \multirow[t]{3}{*}{ Carlton \& Gentiles } & 144 pages & Young Adult & Excerpted Quotes \\
\hline & & & Table of Contents \\
\hline & & & Text Boxes \\
\hline \multirow[t]{3}{*}{ Edwards (2008) } & 64 pages & Ages 4-8 & Artist provided illustrations \\
\hline & & & Color photographs \\
\hline & & & Maps \\
\hline
\end{tabular}




\begin{tabular}{|c|c|c|c|}
\hline Gormley (2008) & 176 pages & Ages 9-12 & $\begin{array}{l}\text { Table of Contents } \\
\text { Source List }\end{array}$ \\
\hline Mendell (2008) & 182 pages & Ages 9-12 & $\begin{array}{l}\text { Bibliography } \\
\text { Black and White Photographs } \\
\text { Excerpted Quotes } \\
\text { Table of Contents }\end{array}$ \\
\hline Thomas (2008) & 256 pages & Ages 9-12 & $\begin{array}{l}\text { Bibliography } \\
\text { Black and White Photographs } \\
\text { Excerpted Quotes } \\
\text { Family Tree } \\
\text { Index } \\
\text { Table of Contents } \\
\text { Text Boxes } \\
\text { World Map }\end{array}$ \\
\hline DeMedeiros (2008) & 24 pages & Ages 9-12 & $\begin{array}{l}\text { Color Photographs } \\
\text { Glossary } \\
\text { Index } \\
\text { Related Websites } \\
\text { Screenshots } \\
\text { Table of Contents } \\
\text { Text boxes } \\
\text { Timeline }\end{array}$ \\
\hline Feinstein (2008) & 24 pages & Ages 4-8 & Color Photographs \\
\hline
\end{tabular}




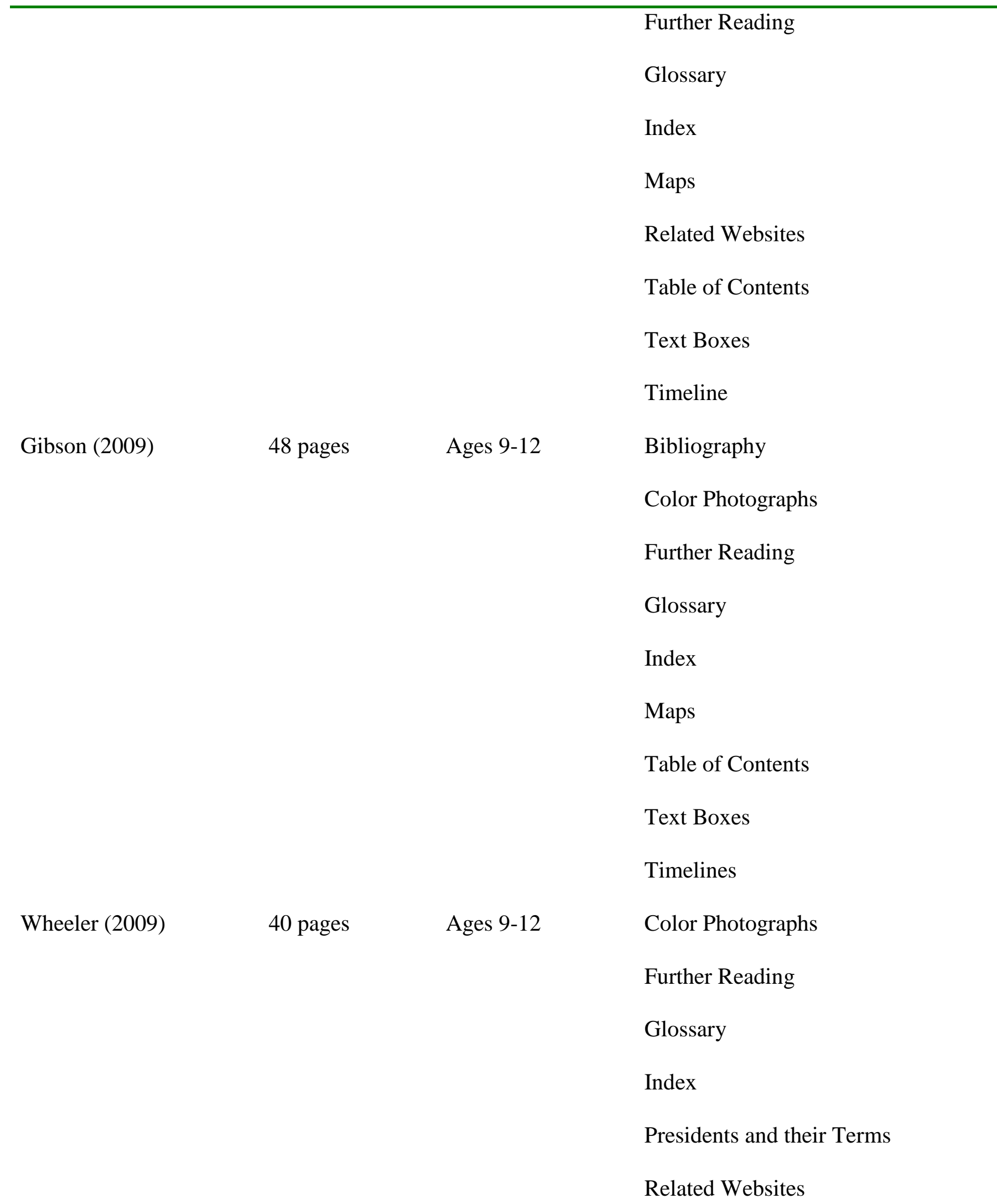




\begin{tabular}{|c|c|c|c|}
\hline & & & Table of Contents \\
\hline & & & $\begin{array}{l}\text { Text Boxes } \\
\text { Timeline }\end{array}$ \\
\hline DeVaney \& DeVaney & 104 pages & Ages 9-12 & Bibliography \\
\hline (2006) & & & Color Photographs \\
\hline & & & Further Reading \\
\hline & & & Index \\
\hline & & & Related Websites \\
\hline & & & Table of Contents \\
\hline & & & Text Boxes \\
\hline & & & Timeline \\
\hline Robinson (2009) & 112 pages & Young Adult & Bibliography \\
\hline & & & Color Photographs \\
\hline & & & Essential Facts \\
\hline & & & Further Reading \\
\hline & & & Glossary \\
\hline & & & Index \\
\hline & & & Places to Visit \\
\hline & & & Related Websites \\
\hline & & & Table of Contents \\
\hline & & & Text Boxes \\
\hline & & & Timeline \\
\hline Schuman (2008) & 128 pages & Ages 9-12 & Bibliography \\
\hline
\end{tabular}


Color Photographs

Further Reading

Index

Related Websites

Table of Contents

Text Boxes

Timeline

World Map

Wagner (2008)

98 pages

Ages 9-12

Color Photographs

Index

Further Reading

Related Websites

Table of Contents

Text Boxes

Timeline

\section{A Qualitative Critical Discourse Analysis ${ }^{\mathrm{ii}}$}

To examine how Obama was storied in children's books, we drew heavily on Williamson’s (2006) discussion about narratives of the American Civil Rights Movement. Williamson posited two primary narratives—a conventional and a revisionist—-through which the black freedom struggle is articulated in U.S. culture. In her explanation, conventional 
framings place the Civil Rights Movement within a national context and emphasize the roles played by the federal government, national organizations, public figures, and established legal apparatus in pushing forward and achieving the civil liberties agenda for African Americans. This conventional version paints the black freedom struggle as driven by a desire for “ judicial and legislative redress"' (p. 39) helped along by an “American goodwill” that operated through existing macro-structures to support black civil rights efforts (p. 37). A revisionist framing counters this conventional storying, stressing the role local forces played in taking on " white intransigence and halfhearted federal support'’(p. 37). In the revisionist stories, she argued, the struggle for civil rights was not propelled by landmark court rulings or by speeches given by prominent black leaders (usually men) but by long-existing grassroots efforts organized by local workers (frequently women) using local churches, among other community structures.

Williamson further described scholarship that troubles the division of the black freedom struggle into the Civil Rights Movement, which has been narratively cast as “good people working together in a nonviolent struggle toward greater inclusion in the American dream”' (p. 41) and the Black Power Movement, inscribed as an offshoot bent on destruction. Williamson described this bifurcating of the struggle thusly:

The Civil Rights Movement represented a shining moment in American democracy that went horribly wrong when it traveled north of the Mason- Dixon Line. At that point, a movement peopled by middle-class blacks with justifiable grievances morphed into an urban, radical, and workingclass phenomenon geared toward the destruction of the social order. (p. 41)

Rather than conveying a narrative of civil rights that articulates an inter-related and demographically dispersed movement, conventional tellings frequently divide and categorize the 
movement in ways that have far-reaching implications for how Americans conceptualize not only the Civil Rights Movement but social change at large.

In evaluating children's biographies on Obama, it is necessary to consider some of the key elements of both the conventional narrative (federal institutions; legal and legislative structures; national organizations; southern locations; middle-class activists) and the revisionist narrative (the inclusion of local, community and grassroots organizations; long-standing activism; a resistance toward dividing the struggle into two movements marked along geographical, class and ideological lines). We argue that the facts of Obama's life complicate a conventional narrative: Born of a bi-racial couple and raised trans-continentally, he has lived in a variety of rural and urban settings and has worked for change using both grassroots and institutional legal/legislative apparatus.

Working from this critical perspective, we used a modified constant comparative method to see how aspects of Obama's life and experiences were depicted across texts. First, the first author read all of the books, conducting open coding in a notebook as she read. Second, we needed a way to compare across a representative sample; the sheer amount of text in the texts made our analysis unweildy. So the research team selected several key events from Obama's personal and professional activities for a more micro-level examination; these events spanned his lifetime (ending before 2006, the time of the earliest published book) and were included in multiple texts. All of the key events we selected were described in Obama's personal memoirs and were therefore available to all of the children's book authors. By “'key events”' we meant collections of experiences from Obama’s life, such as his relationship with his father and his childhood in Indonesia. After working through several layers of analysis, we focused on three key events for close examination: Obama's relationship with 
Reverend Wright and his membership in Trinity United Church of Christ, his work as a community organizer in Chicago, and his responsibilities as an Illinois state senator. We selected these events for closer analysis for two primary reasons: (1) they featured prominently in Obama's own storying of himself and in the public conversations about him and (2) they built (or failed to build) on larger sociohistorical narratives relating to the American Civil Rights Movement. Following Williamson (2006), these events aligned with central features of both the conventional narratives (i.e., reform occurring through judicial and legislative reforms, the importance of prominent people and national structures) and revisionist narratives (i.e., activism based in churches and other local community organizations, the primacy of economic concerns/inequality/dignity). Sections from each text that discussed these events were photocopied and attached to index cards. This new format allowed the research team to easily go back and forth across the texts, comparing how the books portrayed (or failed to portray) Obama's life. The categories outlined in the next section were generated from this comparative work.

\section{Findings}

Although we determined the key events based on their prevalence in Obama's memoirs and media accounts of his life, we found that not all of them were present in all of the children's books, and when they were included, they differed greatly in how they were told. Authors made decisions about the amount of attention they paid to the events as well as how the events were portrayed. We concluded that these differences represented more than surface level variations; to the contrary, the variations led us to speculate about ideological implications. In this findings section we will first discuss how variations were structured within the texts by examining the representation of Obama’s relationship with Wright and Trinity United Church of Christ, his 
work as a Chicago community organizer, and his responsibilities as an Illinois state senator. We will then look across texts at his community organizing and role as an Illinois state senator to illustrate how their use relates to larger sociocultural narratives.

\section{Inclusions/Omissions}

Events took on differing levels of importance, in part, by how much attention they received in the books and what pieces of information were included or omitted. This particular difference was most striking in the books' treatment of Reverend Jeremiah Wright and Obama's membership and participation in Chicago's Trinity United Church of Christ.

As can be seen in Table 2, the treatment of this topic varied greatly among texts. This omission was particularly interesting to us given the importance of this event within Obama's memoirs. In fact, one memoir's title, Audacity of Hope (2006), was taken from a sermon by Reverend Wright.

A look at the biographies provided initial but limited evidence of a correlation between text type (i.e., textbook, narrative chapter book) and this topic. For example, narrative chapter book biographies tended to include Wright/Trinity while the textbook biographies tended to omit that aspect of Obama's life. However, we note that the correlation is not strong enough to be predictive since there were also exceptions. One textbook biography included Wright/Trinity while one chapter book omitted it.

But authors' decisions were more complex than simply to include or omit reference to this time in Obama's life; authors also chose how extensively to use this event. As can be seen by looking at the two tables, inclusion/omission did not necessarily correlate with the books' page length. Brill's (2006) text was the most limited on this topic. In her 48 page narrative 
chapter book on Obama, one sentence in one text box referred to Wright/Trinity: “He and his family belong to Chicago's

Trinity United Church of Christ”' (p. 30). On the other end of the spectrum, the Gormley (2008) and Carlton and Gentiles (2008) books provide more than 10 paragraphs on the topic; both describe the close friendship between Obama and Wright, the social justice focus of the church, the controversial nature of Wright's sermons, and the resulting impact of that controversy on Obama’s campaign.

Table 2

Wright/Trinity Community Organizer Illinois State Senator

\begin{tabular}{llll}
\hline \multicolumn{2}{l}{ Narrative chapter-book format } & & \\
\hline Brill (2006) & Cursory & Included & Included \\
Carlton \& Gentiles & Included & Included & Included \\
(2008) & & \\
Edwards (2008) & Omitted & Included & Included \\
Gormley (2008) & Included & Included & Included \\
Mendell (2008) & Included & Included & Included \\
Thomas (2008) & Included & Included & Included \\
Textbook-0rganization & & \\
DeMedeiros (2008) & Omitted & Cursory & Cursory \\
Feinstein (2008) & Omitted & Cursory & Cursory \\
Gibson (2009) & Included & Included & Included \\
Wheeler (2009) & Omitted & Included & Included
\end{tabular}

Narrative/Textbook Hybrids 


$\begin{array}{llll}\text { DeVaney \& } & \text { Omitted } & \text { Included } & \text { Included } \\ \text { DeVaney (2006) } & & & \\ \text { Robinson (2009) } & \text { Omitted } & \text { Included } & \text { Included } \\ \text { Schuman (2008) } & \text { Cursory } & \text { Included } & \text { Included } \\ \text { Wagner (2008) } & \text { Included } & \text { Included } & \text { Included }\end{array}$

\section{Framing}

The decision to include, exclude, or provide only cursory attention to events was not the only way texts differed; how authors framed the events was also informative. For example, while the Gormley (2008) and Carlton and Gentiles (2008) texts both provide extensive description of the Wright/Trinity event and include the information mentioned in the previous paragraph, they also differ in important ways. The former includes the information that Obama was drawn to the church, in part, because of a sign on the church lawn protesting apartheid. The latter- published by a Christian publisher-included Obama's personal conversion story, a story not included in any other text we examined. In choosing the facts to describe an event, providing accompanying analysis, and making decisions for how the information is presented, authors set the stage for a variety of reader experiences. For example, Schuman (2008) used the Wright/Trinity event as primarily a matter of setting; he described the church building as the location for Barack and Michelle's wedding and mentioned the closeness of the new building structure to the original church, although he also noted the importance of Wright's “Audacity of Hope” sermon to Obama. Other texts showed more layered tacks by detailing the controversial impact of Wright on Obama’s political career (Carlton and Gentiles, 2008; Gibson, 2009; Gormley, 2008; Thomas, 2008), the role of African American churches in the fight for equity (Carlton and Gentiles, 2008; 
Gormley, 2008; Mendell, 2008; Thomas, 2008; Wagner, 2008), the influence of Wright/Trinity on Obama’s internal spiritual dilemmas (Carlton and Gentiles, 2008; Thomas, 2008;

Wagner, 2008), and the close personal friendship between Obama and Reverend

Wright (Carlton and Gentiles, 2008; Gormley, 2008; Mendell, 2008). These more complex framings of this topic are particularly striking when compared with Brill’s

(2006) brief reference to church membership and Schuman's (2008) attention to the inanimate church building.

\section{Narrative Constructions}

The importance of local, community activism has been a central thread in civil rights narratives, particularly those written from revisionist accounts (Williamson, 2006). Obama's highlighting of his work as a community organizer in his memoirs and on the campaign trail can be seen as part of this ongoing narrative. Obama spent 3 years as a community organizer in Chicago. As with Wright/Trinity, the amount and type of information about Obama's community organizing experiences included in the texts and how that information was framed pointed to different possible reading experiences for children.

Two of the texts (Feinstein, 2008; DeMedeiros, 2008) mentioned Obama’s community organizing work only briefly. Feinstein (2008) wrote one sentence, “For the next few years, Barack worked in Chicago helping poor people in housing projects make their lives better’' (p. 14); and DeMedeiros (2008) wrote two, “After graduating from university, Barack went to Chicago to work as a community organizer. In this job, he worked with churches to improve conditions for people in poor neighborhoods on Chicago’s South Side’' (p. 8). These fairly declarative and cursory representations contrasted with other texts that presented Obama's time as a community organizer as a transformative learning experience. For example, Carlton and 
Gentiles (2008) presented this time of Obama’s life as “a foundational and pivotal part of his civic education. Ultimately, this experience has both led to and greatly influenced his historic run for the presidency of the United States”' (p. 32). Although the space allotted to this event is roughly the same for these three texts, the intent of the words differ. The Feinstein (2008) and DeMedeiros (2008) books presented Obama’s work within a social justice framework while the Carlton and Gentiles (2008) text framed it as the impetus for his quest for the presidency. In other words, while some texts presented his community organizing work as a stepping stone to more prominent work, others presented it as foundational to Obama as a person. Depending on the text, Obama’s presidency can be seen as social justice fulfilled, as a way to continue to work for social justice, or as a combination of the two.

The texts also varied in how they set Obama's work in community organizing within (and in opposition to) trends within larger sociohistorical contexts. Carlton and Gentiles (2008) offered young readers a definition of community organizing that looked across U.S. social movements:

Community organizing is an approach for developing power and relationships throughout local institutions such as congregations, unions, and associations. The U.S. civil rights movement, the anti-war movements, and the Chicano movement all influenced and were influenced by ideas of neighborhood organizing. (pp. 32-33)

Similarly, others texts framed descriptions of community organizing in conjunction with references to the Great Migration (1915-1930) of African Americans to the northern U.S. (Gormley, 2008), the movement overseas of steel industry jobs from Chicago (DeVaney and DeVaney, 2006), and the relationship of white flight and urban decay (Gormley, 2008; Thomas, 2008). While these books discussed the topic within larger trends and other movements, some 
texts positioned Obama’s community organizing work as opposing existing sociopolitical currents. For example, in addition to discussions of the role of community organizers, conservative and liberal ideology, and Obama’s own beliefs, Schuman (2008) also included a text box describing President Ronald Reagan, his conservative policies, and Obama’s desire to counteract them.

Other books (Brill, 2006; Edwards, 2007; DeVaney and DeVaney, 2006; Robinson, 2009), however, opted not to explicitly link Obama’s story to any particular sociohistorical background. By removing him from a sociohistorical context, Brill (2006) presented Obama as more of an individual, a change agent working determinedly on his own. Though he included a text box that alluded to a longer civil rights tradition (i.e., referring to Obama’s heroes, Martin Luther King, Jr., Mahatma Gandhi, and Cesar Chavez), the text box was nestled within the following paragraph:

In the beginning, Obama called meetings where few people showed. Church leaders closed doors on his ideas. After several disappointments, Obama found some success. He helped bring job training programs to poor neighborhoods. He gathered a busload of parents from a housing project and drove them to the downtown Chicago Housing Authority office. With Obama’s support, they insisted on asbestos testing and removal for their apartments. (p. 29)

This type of description comes quite close to painting Obama as an individual hero or role model who went into a neighborhood to fix things singlehandedly (Campbell, 1968; Meyers et al., 2009). Other books portrayed him as an individual change agent while also acknowledging the local context (though to varying degrees). Edwards (2007) wrote that, “At this time in Illinois, many factories had closed. Many people were out of work. They were desperate. And the 
government wasn't helping enough’' (p. 28). He then included a description of how bad things were, and how "Barack did what he could to fix problems" (p. 29).

This lone-hero description is especially striking when contrasted with other texts (Gibson, 2009; Schuman, 2008; Thomas, 2008; Wheeler, 2009) that described his relationships with organizations that shared his goals or his side-by-side work with members of the community. In addition, some texts (Carlton and Gentiles, 2008; Gibson, 2009; Gormley, 2008; Wagner, 2008) talked about the professional and personal impact the community organizing work had on Obama—in other words, the effects were mutual. Children's books related to racial equity, particularly those focused on the Civil Rights Movement, have been criticized for portraying change as occurring through the work of one agent (i.e., Rosa Parks, Martin Luther King, Jr., etc.) who seemingly worked alone (Kohl, 1995b; Landorf and Lowenstein, 2004; Williamson, 2006). How the books portrayed Obama as a community organizer pointed to whether the president's story was animated through a conventional or revisionist narrative of activism, and, in turn, to which notions of social change children have access.

\section{Illinois State Senator}

Obama spent 8 years as a state senator (January 1997-November 2004), during which time he worked with a wide range of people on a variety of issues. It was an important time for him personally (his two daughters, Sasha and Malia, were born), and professionally he experienced political struggles and participated in the national political scene. All fourteen books that we looked at included this period in Obama's life, not surprisingly, given the substantial amount of information available to authors. The availability of information provided for considerable selection, which in turn, allowed for a large range of framing opportunities.

As with Wright/Trinity and community organizing, some of the texts (Feinstein, 
2008; DeMedeiros, 2008) provided a cursory overview of this period in Obama’s life. But even cursory treatment indicated ideological framings. Feinstein (2008) devoted three sentences to Obama's interest in helping people.

Barack decided he could do the most good for the most people if he got into politics. In 1996, he won an election for Illinois state senator. For seven years, he worked to pass laws that helped the people of Illinois. (p. 19)

In contrast with the revisionist civil rights narrative that stresses grassroots change, this excerpt reflects the conventional narrative that stresses the role of legislators and judges in making and enforcing policy on behalf of the people.

Obama's political acumen was also depicted differently across texts. Ten of the fourteen texts (Brill, 2006; Carlton and Gentiles, 2008; DeVaney and DeVaney, 2006; Gibson, 2009; Gormley, 2008; Mendell, 2008; Schuman, 2008; Thomas, 2008; Wheeler, 2009; Wagner, 2008) described him as someone who worked well with others, most referring to his ability to work across the aisle. As Brill (2006) stated "[t]o accomplish so much, Obama needed the respect of other state representatives. He had a gift for reaching out to opponents to find agreement'” (pp. 37-38). Drawing on conventional civil rights narratives (Williamson, 2006), Obama was presented as a certain type of leader who got things done by working well with others. Only one of the fourteen texts (Carlton and Gentiles, 2008) included reference to Obama's description of politics as a "full-contact sport" and himself as “"[minding] neither the sharp elbows nor the occasional blind-side hit”' (Obama, quoted in Carlton and Gentiles, pp. 61-62). The fact that most of the texts excluded this quote (or provided any evidence of Obama as someone who would engage in aggressive political tactics) provided support for our conclusion that the conventional narrative predominated across these children's books. 


\section{Discussion}

Urban (2001) maintained that culture is its own product, a “'ghost-like journey [that] takes place along pathways, social pathways, that it itself lays down’’ (p. 1). Children’s books are mechanisms of this cultural self-production - the stories children read, and the ideologies those books manifest, become part of children's narrative of the cultures in which they live. Educational researchers have examined the role of ideology in children's literature by exploring how such issues as class (Travis, 2007), gender (Baker, 2006), colorblindness (Lea, 2006), and political topics (Jenkins, 2002) are both critiqued and reified in books written for children. These investigations remind us as educators to think carefully about the influence children's books have on their readers.

All books offer potential for children’s language and literacy learning (Kohl, 1995a), particularly in those contexts in which children are asked to think critically about texts (Landorf and Lowenstein, 2004). It is commonplace in literacy education for teachers to ask young readers to use personal experiences to better understand the books they read, but we also must recognize that texts influence student lives and the way they view the social worlds of which they are a part (McGinley and Kamberelis, 1996). In this way, child/text/culture is co-constructive: 286 Children’s Literature in Education (2010) 41:273-290 123 texts act upon their child readers, and children, in turn, act upon the texts as agents of replication, re-storying, and dissemination as they carry stories forward.

In thinking about the complex relationship between text, reader, and culture, it becomes important for educators to turn a critical eye to the in-process storying of the current American president. By closely attending to the elements of Obama biographies written for children, 
educators can better scaffold children's own critical work in understanding the texts and thinking critically about their own lives.

The children's books we looked at reflected the complexity of Obama's life history as authors worked within both conventional and revisionist narratives. For example, by depicting Obama as a lone hero figure who as a legislator formed alliances across party lines, Brill's (2006) storying downplayed the role of grassroots organizations while highlighting Obama's ability to work well with disparate elected officials. Carlton and Gentiles (2008), on the other hand, accentuated the role of community organizing in social change in America but also stressed Obama’s success at achieving legislative cooperation. In their text, his political acumen is depicted as neither local nor national but both.

How Obama is storied in children's books is critical not only because the storying contributes to children's understandings of themselves within a cultural context, but because it also contributes to their notion of social and cultural change. As Williamson (2006) noted, conventional narratives of the Civil Rights Movement support the conclusion " that moral suasion, normative and institutionalized routes to social reform, interracialism, and nonviolence are the only valid means of bringing grievances." Other dissidence is “destructive, racist, unpatriotic, and illegitimate’' (pp. 41-41). Such a position effaces the complexity of social change and paints the lengthy, tense, collective, and unruly work of activism as best performed within the mechanisms of existing power structures. Revisionist scholars would argue that such depictions limit the terms for change itself and, in fact, mitigate against change (p. 42).

In constructing Obama's biography for young readers, children's book authors had access to a combination of resources from which to piece together different narratives that highlighted and erased various aspects of his life. These emphases and erasures were deliberate—writing, 
after all, is a decision-making process (Graves and Kittle, 2005) — and as such underscore the necessity of critical literacy. In other words, the different portrayals are significant to discourse on equity and the perceptions children are left to internalize. We also know, though, that this sort of critical thinking is in short supply in too many classrooms, a situation that is particularly problematic for students who are members of traditionally marginalized groups (Dozier et al., 2006). It is difficult for students to push back against sanctioned texts. Texts about a president, handed to children by a teacher or media specialist, have a particularly strong aura of authority.

Returning to the query that started our investigation, we think again about the decisions facing media specialists, teachers, parents, and caregivers as they make choices about which Obama biographies to offer to children. Confronted with selecting texts, adults can ask questions of the books before they buy: In what context does this book place Obama's story? Does it situate it in relation to other sociohistorical events? Does it cast Obama in the role of the lone hero, or does it acknowledge other people, organizations, and institutions as instrumental in his work? Depending on the answer, what viewpoint might the author hold about change and agency in history? But while we suggest that it is important for adults to understand that discourses underlie each text, it is not sufficient. Children need to be provided with the opportunity to engage in their own critical readings of the texts. Questions can guide their inquiry: Is it possible for an individual to achieve change alone? What stories do you know about Obama that are left out of this text? Whose stories might be missing in this account of Obama's life? Why do you think the author decided to include some stories of Obama's life but not others? As more books about the 44th president are published, students will need to be fluent users of critical literacy tools to make their own judgments about the storying and re-storying of themselves, their times, and their culture. 


\section{References}

Agger, B. (1989). Fast capitalism: A critical theory of significance. Urbana, IL: University of Illinois Press.

Apple, M. W., \& Christian-Smith, L. K. (1991). The politics of the textbook. New York: Routledge.

Baker, D.F. (2006). What we found on our journey through fantasy land. Children's Literature in Education, 37, 237-251.

Banks, C. A. M. (1996). Intellectual leadership and African American challenges to metanarratives. In J.A. Banks (Ed.), Multicultural education, transformative knowledge, and action: Historical and contemporary perspectives (pp. 46-63). New York: Teachers College Press.

Banks, J. A. (2001). Citizenship education and diversity: Implications for teacher education. Journal of Teacher Education, 52(5), 5-16.

Bruner, J. (1987/2004). Life as narrative. Social Research, 71(3), 691-710.

Campbell, J. (1968). The hero with a thousand faces. Princeton, NJ: Princeton University Press.

Clandinin, D. J., \& Connelly, F. M. (1999). Storying and restorying ourselves: Narrative and reflection. In A. Chen \& J. Van Maanen (Eds.), The reflective spin: Case studies of teachers in higher education transforming action. Singapore: World Scientific Publishing Company.

Dozier, C., Johnston, P., \& Rogers, R. (2006). Critical literacy, critical teaching: Tools for preparing responsive teachers. New York: Teachers College Press.

Duke, N., \& Tower, C. (2004). Nonfiction texts for young readers. In J.V. Hoffman \& D.L. Schallert (Eds.), The texts in elementary classrooms. Mahwah, NJ: Erlbaum. 
Fox, D. L., \& Short, K. G. (Eds.). (2003). Stories matter: The complexity of cultural authenticity in children's literature. Urbana, IL: NCTE.

Gee, J. P. (1996). Social linguistics and literacies: Ideology in discourses (2nd ed.). New York: RoutledgeFalmer.

Gee, J. P. (2000). New people in new worlds: Networks, the new capitalism and schools. In B. Cope \& M. Kalantzis (Eds.), Multiliteracies: Literacy learning and the design of social futures (pp. 43- 68). New York: Routledge.

Graves, D., \& Kittle, P. (2005). Inside writing: How to teach the details of the craft. Portsmouth, NH: Heinemann.

Henderson, D. L. (2005). Authenticity and accuracy: The continuing debate. In D. L. Henderson \& J. P. May (Eds.), Exploring culturally diverse literature for children and adolescents: Learning to listen in new ways (pp. 266-276). Boston: Pearson.

Jenkins, E. (2002). Adult agendas in publishing South African folktales for children. Children's Literature in Education, 33(4), 269-284.

Kohl, H. (1995). Should we burn Babar: Questioning power in children's literature. In Should we burn Babar?: Essays on children's literature and the power of stories (pp. 3-29). New York: The New Press.

Kohl, H. (1995). The story of Rosa Parks and the Montgomery bus boycott revisited. In Should we burn Babar?: Essays on children's literature and the power of stories (pp. 30-56). New York: The New Press.

Landorf, H., \& Lowenstein, E. (2004). The Rosa Parks “myth”: A third grade historical investigation. Social Studies and the Young Learner, 16(5), 5-9. 
Lea, S. G. (2006). Seeing beyond sameness: Using The Giver to challenge colorblind ideology. Children's Literature in Education, 37(1), 51-67.

Luke, C., DeCastell, S., \& Luke, A. (1989). Beyond criticism: The authority of the school textbook. In S. DeCastell, A. Luke, \& C. Luke (Eds.), Language, authority, and criticism: Readings on the school textbook (pp. 245-260). New York: Falmer.

McGinley, W., \& Kamberelis, G. (1996). Maniac Magee and Ragtime Turnpie: Children negotiating self and world through reading and writing. Research in the Teaching of English, 30(1), 75-113.

McNair, J. C. (2008). The representation of authors and illustrators of color in school-based book clubs. Language Arts, 85(3), 193-201.

Meyers, L. E., Holbrook, T., \& May, L. A. (2009). Beyond heroes and role models: Using biographies to develop young change agents. Social Studies and the Young Learner, 21(3), 1014.

Obama, B. (2004). Dreams from my father: A story of race and inheritance. New York: Crown Publishing Group.

Obama, B. (2006). The audacity of hope: Thoughts on reclaiming the American dream. New York: Crown Publishing Group.

Taxel, J. (1981). The outsiders of the American Revolution: The selective tradition in children's fiction. Interchange, 12(2-3), 206-228.

Taxel, J. (1997). Multicultural literature and the politics of reaction. Teachers College Record, 98(3), 417-448.

Taxel, J. (2002). Children's literature at the turn of the century: Toward a political economy of the publishing industry. Research in the Teaching of English, 37, 145-197. 
Tolson, N. D. (2005). The Black aesthetic within Black children’s literature. In D. L. Henderson \& J. P. May (Eds.), Exploring culturally diverse literature for children and adolescents: Learning to listen in new ways (pp. 65-78). Boston: Pearson.

Travis, M. (2007). Mixed messages: The problem of class in Mary Norton’s Borrowers Series. Children's Literature in Education, 38, 187-194.

Urban, G. (2001). Metaculture: How culture moves through the world. Minneapolis: University of Minnesota Press.

Wertsch, J. (2002). Voices of collective remembering. Cambridge: University Press.

Williamson, J. A. (2006). A tale of two movements: The power and consequences of misremembering Brown. Yearbook of the National Society for the Study of Education, 105(2), 36-57.

Wise, T. (2009). Between Barack and a hard place: Racism and white denial in the age of Obama. San Francisco: City Lights Books.

Yokota, J., \& Bates, A. (2005). Asian American literature: Voices and images of authenticity. In D. L. Henderson \& J. P. May (Eds.), Exploring culturally diverse literature for children and adolescents: Learning to listen in new ways (pp. 323-335). Boston: Pearson.

\section{Children's Literature}

Grimes, N. (2008). Barack Obama: Son of promise, child of hope. New York: Simon \& Schuster.

Nave, J. (2008). Obama's pajamas. Bloomington, IN: AuthorHouse (Illustrated by Barry Lane). Winter, J. (2008). Barack. New York: HarperCollins (Illustrated by AG Ford). 
Brill, M. T. (2006). Barack Obama: Working to make a difference (Gateway Biographies). Minneapolis: Millbrook Press.

Carlton, B., \& Gentiles, A. (2008). Barack Obama: An American story. Grand Rapids, MI: Zondervan.

DeMedeiros, M. (2008). Barack Obama (Remarkable People). New York: Weigl Publishers Inc.

Devaney, S., \& Devaney, M. (2006). Barack Obama (People in the News). Detroit: Lucent Books.

Edwards, R. (2007). Barack Obama: An American story. New York: Grosset \& Dunlap.

Feinstein, S. (2008). Barack Obama (African-American Heroes). Berkeley Heights, NJ: Enslow Publishers, Inc.

Gibson, K. B. (2009). The Obama view: The historic fight for the 2008 Democratic nomination (Monumental Milestones: Great Events of Modern Times). Hockessin, DE: Mitchell Lane Publishers.

Gormley, B. (2008). Barack Obama: Our 44th President. New York: Aladdin.

Mendell, D. (2008). Obama: A promise of change: An adaptation for young readers of S. Thomsen’s Obama: From promise to power. New York: HarperCollins.

Robinson, T. (2009). Barack Obama-44th president (Essential Lives Set 3). Edina, MN: ABDO Publishing Company.

Schuman, M. A. (2008). Barack Obama: "We are one people’’ (African-American Biography Library). Berkeley Heights, NJ: Enslow Publishers, Inc.

Thomas, G. (2008). Yes we can: A biography of President Barack Obama. New York: Fiewel and Friends. 
Wagner, H. L. (2008). Barack Obama (Black Americans of Achievement: Legacy Edition). New York: Infobase Publishing.

Wheeler, J.C. (2009). Barack Obama (The United States Presidents). Edina, MN: ABDO Publishing Company.

'While all the books analyzed were biographies, picture books (e.g., Grimes, 2008; Nave, 2008; Winter, 2008) were excluded from the data because the writing styles were significantly different from the other books.

ii A reflexive note. We are three educational literacy researchers from middle-class, European American backgrounds who approached this study through a critical lens. We took the position that neutral texts do not exist; all texts are written from ideological perspectives, including this article. Current national discussions concerning diversity, brought to the forefront by the 2008 election, point to the need for educators to pay more attention to critical literacy in the teaching of children, a project in which we enthusiastically engage. However, our positions as European American researchers raise the question, rightfully so, of our suitability for this undertaking. We strongly agree that emic perspectives are critical to all research and acknowledge that we are outsiders to many of the experiences, grounded in African American cultures, which informed Obama's personal and political maturation. However, we operate from a belief that because of Obama's prominence as the U.S. President, critiques of the sociocultural narrative of him benefit from multiple perspectives and epistemological and ontological approaches, of which we here present one. 